\title{
Identification of organic hydroperoxides and peroxy acids using atmospheric pressure chemical ionization-tandem mass spectrometry (APCI-MS/MS): application to secondary organic aerosol
}

\author{
Shouming Zhou ${ }^{1}$, Jean C. Rivera-Rios ${ }^{2,3}$, Frank N. Keutsch ${ }^{2,3}$, and Jonathan P. D. Abbatt ${ }^{1}$ \\ ${ }^{1}$ Department of Chemistry, University of Toronto, Toronto, Canada \\ ${ }^{2}$ Department of Chemistry and Chemical Biology, Harvard University, Cambridge, MA, USA \\ ${ }^{3}$ School of Engineering and Applied Sciences, Harvard University, Cambridge, MA, USA
}

Correspondence: Shouming Zhou (szhou@chem.utoronto.ca)

Received: 3 November 2017 - Discussion started: 4 January 2018

Revised: 17 April 2018 - Accepted: 10 May 2018 - Published: 30 May 2018

\begin{abstract}
Molecules with hydroperoxide functional groups are of extreme importance to both the atmospheric and biological chemistry fields. In this work, an analytical method is presented for the identification of organic hydroperoxides and peroxy acids (ROOH) by direct infusion of liquid samples into a positive-ion atmospheric pressure chemical ionization-tandem mass spectrometer ((+)-APCI-MS/MS). Under collisional dissociation conditions, a characteristic neutral loss of $51 \mathrm{Da}$ (arising from loss of $\mathrm{H}_{2} \mathrm{O}_{2}+\mathrm{NH}_{3}$ ) from ammonium adducts of the molecular ions $\left(\left[\mathrm{M}+\mathrm{NH}_{4}\right]^{+}\right)$ is observed for $\mathrm{ROOH}$ standards (i.e. cumene hydroperoxide, isoprene-4-hydroxy-3-hydroperoxide (ISOPOOH), tertbutyl hydroperoxide, 2-butanone peroxide and peracetic acid), as well as the $\mathrm{ROOH}$ formed from the reactions of $\mathrm{H}_{2} \mathrm{O}_{2}$ with aldehydes (i.e. acetaldehyde, hexanal, glyoxal and methylglyoxal). This new ROOH detection method was applied to methanol extracts of secondary organic aerosol (SOA) material generated from ozonolysis of $\alpha$-pinene, indicating a number of $\mathrm{ROOH}$ molecules in the SOA material. While the full-scan mass spectrum of SOA demonstrates the presence of monomers $(\mathrm{m} / z=80-250)$, dimers $(m / z=250-450)$ and trimers $(m / z=450-600)$, the neutral loss scan shows that the $\mathrm{ROOH}$ products all have masses less than $300 \mathrm{Da}$, indicating that $\mathrm{ROOH}$ molecules may not contribute significantly to the SOA oligomeric content. We anticipate this method could also be applied to biological systems with considerable value.
\end{abstract}

\section{Introduction}

Organic hydroperoxides and peroxy acids $(\mathrm{ROOH})$ are produced by the gas-phase oxidation of volatile organic compounds (VOCs) (Jackson et al., 1999; Lee et al., 2000; Atkinson and Arey, 2003), as well as in cloud and wet aerosols (Zhao et al., 2013; Lim and Turpin, 2015). Atmospheric oxidation of VOCs leads to secondary organic aerosol (SOA), an important fraction of the atmospheric aerosol burden. Both modeling and experimental studies indicate that organic peroxides (i.e. organic peroxides (ROOR) and $\mathrm{ROOH}$ species) are major components of SOA (Jenkin, 2004; Bonn et al., 2004; Docherty et al., 2005). In recent years, ROOH in particular have been proposed to be involved in high-molecularweight products leading to SOA formation (Krapf et al., 2016; Kristensen et al., 2016; Sakamoto et al., 2017). Organic peroxides are also widely used industrially as radical initiators; bleaching and disinfecting agents; and reactive intermediates in the polymer, food and pharmaceutical industries (Odian, 2004; Moll et al., 1979; Reile et al., 2011). In biological systems, ROOH are formed from the reactions of radicals and singlet oxygen with amino acids, peptides and proteins (Gebicki and Gebicki, 1993; Wright et al., 2002; Agon et al., 2006; Morgan et al., 2008). Classified as one component of reactive oxygen species (ROS), ROOH are hazardous, irritating to skin, eyes and mucous membranes. They also cause progressive oxidative damage, cell death and even cancer (Liou and Storz, 2010). 
Despite their importance in both atmospheric and biological chemistry, the identification of specific ROOH molecules in a complex mixture remains analytically challenging. There are two reasons for this: (i) unavailability of the ROOH standards because of their thermally unstable nature (Bach et al., 1996) and (ii) the lack of appropriate analytical techniques. So far, the analysis of $\mathrm{ROOH}$ in the condensed phase has mainly been done by means of chemical assays, such as the iodometric (Docherty et al., 2005; Banerjee and Budke, 1964), triphenylphosphine (Nakamura and Maeda, 1991), ferrous oxidation-xylenol orange (Wasylaschuk et al., 2007), and horseradish peroxidase approaches (Walker et al., 2006; Hong et al., 2008). These techniques react $\mathrm{ROOH}$ with reducing agents followed by analysis of the reaction products. $\mathrm{ROOH}$ have also been analyzed by high-performance liquid chromatography (HPLC) analysis followed by the postcolumn chemical derivatization method (Valverde-Canossa et al., 2005; Francois et al., 2005; Hasson et al., 2001).

The disadvantage of the assay techniques is that they measure total peroxide content (some combination of organic peroxides, organic hydroperoxides, and hydrogen peroxide) and are not able to identify specific molecules. There are limited studies on direct analysis of ROOH in the literature. Using electrospray ionization-mass spectrometry (ESI-MS), Hui et al. (2012a, b) identified ROOH formed from the oxidation of cholesteryl ester, reporting ammonium and sodium adducts of the $\mathrm{ROOH}$ molecular ions under positive ion mode and acetate adducts of $\mathrm{ROOH}$ molecular ions under negative ion mode (Hui et al., 2012a, b). Reinnig et al. (2009) identified $\mathrm{ROOH}$ using online ion trap mass spectrometry, proposing that neutral loss (NL) of $34 \mathrm{Da}$ (loss of $\mathrm{H}_{2} \mathrm{O}_{2}$ ) from the protonated molecular ions is a characteristic fragmentation route for $\mathrm{ROOH}$. Using this technique, the authors identified three $\mathrm{ROOH}$ molecules from SOA generated from reaction of $\alpha$-pinene and ozone (Reinnig et al., 2009).

Recently, using high-resolution mass spectrometry, a number of studies have proposed $\mathrm{ROOH}$ detection arising from atmospheric oxidation of biogenic organics (Zhang et al., 2017; Riva et al., 2017). However, due to the fact that the high-resolution mass spectrometry can only provide elemental composition of the molecules, the identification of $\mathrm{ROOH}$ in the reaction systems remains speculative.

In the present work, a positive-ion atmospheric pressure chemical ionization-tandem mass spectrometer $((+)$-APCIMS/MS) is applied to identify specific ROOH molecules. The analytical method is developed by using $\mathrm{ROOH}$ commercial standards and $\mathrm{ROOH}$ molecules that are generated from the reactions of aldehydes with $\mathrm{H}_{2} \mathrm{O}_{2}$. The method is applied to SOA formed from ozonolysis of $\alpha$-pinene, and a number of $\mathrm{ROOH}$ molecules are identified. The goal of this work is to provide an analytical technique that can widely be applied in not only the atmospheric chemistry field but also other settings.

\section{Experimental section}

\subsection{Chemicals and reagents}

Cumene hydroperoxide $(80 \%)$, tert-butyl hydroperoxide (35\%), 2-butanone peroxide (35\%), peracetic acid (32\%), di-tert-butyl peroxide (98\%), benzoyl peroxide ( $\geq 98 \%$ ), di(dodecanoyl) peroxide (97\%), 2-nonenal (97\%), mesoerythritol ( $\geq 99 \%)$, cis-pinonic acid $(98 \%)$, formaldehyde (37\%), acetaldehyde (>99\%), hexanal $(98 \%)$, methyl glyoxal $(40 \%)$, glyoxal $(40 \%)$, hydrogen peroxide $\left(\mathrm{H}_{2} \mathrm{O}_{2}\right.$, $30 \%), \alpha$-pinene $(\geq 99 \%)$ and ammonium acetate $(\geq$ $99.99 \%$ ) are all purchased from Sigma-Aldrich (Canada). Isoprene-4-hydrox-3-hydroperoxide (ISOPOOH) is synthesized according to the literature (Rivera-Rios et al., 2014). Methanol (MeOH, LC-MS grade) is purchased from VWR, Canada. All the chemicals and reagents are used as received.

\subsection{Sample preparation and reactions of aldehydes with $\mathrm{H}_{2} \mathrm{O}_{2}$}

Stock solutions for ROOH standards (i.e. cumene hydroperoxide, ISOPOOH, tert-butyl hydroperoxide, 2-butanone peroxide and peracetic acid), other peroxides (di-tert-butyl peroxide, benzoyl peroxide and di(dodecanoyl) peroxide), 2 nonenal, meso-erythritol and cis-pinonic acid are prepared by dissolution of the substances in $\mathrm{MeOH}(2.0-10 \mathrm{mM})$. One hundred microliters of stock solutions are further diluted in $\mathrm{MeOH}$ to a final volume of $1 \mathrm{~mL}$ for mass spectrometry analysis. In some cases, ammonium acetate (AA) is added $(\sim 5 \mathrm{mM})$ to enhance the signal for the ammonium adducts of the molecular ions in the mass spectra.

Reactions of the selected aldehydes (i.e. formaldehyde, acetaldehyde, hexanal, glyoxal and methyl glyoxal) with $\mathrm{H}_{2} \mathrm{O}_{2}$ are performed by mixing the reactants in $\mathrm{MeOH}(\sim 3 \mathrm{mM}$ and $\sim 13 \mathrm{mM}$ for aldehydes and $\mathrm{H}_{2} \mathrm{O}_{2}$, respectively) at room temperature $(295 \pm 3 \mathrm{~K})$ for $\sim 10 \mathrm{~min}$. AA is added $(\sim 5 \mathrm{mM})$ before the samples are analyzed. Sample blanks (i.e. aldehydes $+\mathrm{AA}$ and $\mathrm{H}_{2} \mathrm{O}_{2}+\mathrm{AA}$ ) are prepared and analyzed in the same manner as the reaction mixtures.

\subsection{Secondary organic aerosol (SOA) generation and collection}

SOA is generated in a steady-state manner in a $1 \mathrm{~m}^{3}$ Teflon (FEP) chamber from gas-phase reaction of $\alpha$-pinene with ozone (Aljawhary et al., 2013). $\alpha$-Pinene is introduced into the chamber by passing a $\sim 2 \mathrm{~mL} \mathrm{~min}^{-1}$ nitrogen through a bubbler containing $\alpha$-pinene that is chilled to $-20^{\circ} \mathrm{C}$ and mixed with $5 \mathrm{Lmin}^{-1}$ purified air. Ozone is generated by passing $\sim 10 \mathrm{~L} \mathrm{~min}^{-1}$ purified air through a mercury lamp. The final concentration of ozone is monitored to be $\sim 7.4 \times$ $10^{12}$ molecules $\mathrm{cm}^{-3}$ by a UV photometric ozone analyzer (Thermo Model 49i), and the $\alpha$-pinene concentration is estimated to be $\sim 3.7 \times 10^{12}$ molecules $\mathrm{cm}^{-3}$. 
SOA generation is confirmed by a Scanning Mobility Particle Sizer (SMPS, Model 3034) and collected on quartz fiber filters ( $47 \mathrm{~mm}$ diameter) for $72 \mathrm{~h}$ at a flow rate of $\sim$ $15 \mathrm{~L} \mathrm{~min}^{-1}$. The filters are preheated at $500^{\circ} \mathrm{C}$ for $24 \mathrm{~h}$ to remove organic impurities before SOA collection. After SOA collection, the filter is extracted with $10 \mathrm{~mL} \mathrm{MeOH}$, and the extract is immediately analyzed by the mass spectrometer.

\subsection{Atmospheric pressure chemical ionization-tandem mass spectrometer (APCI-MS/MS)}

A unit resolution APCI-MS/MS instrument (Thermo TSQ Endura) is operated in positive ion mode with direct infusion of the samples into the mass spectrometer. The sample is injected at a flow rate of $10 \mu \mathrm{Lmin}^{-1}$ using a syringe pump (Chemyx, Inc., USA; model: Fusion 101) to the APCI source through polyether ether ketone (PEEK) tubing. The spray voltage is set at $+2500 \mathrm{~V}$; vaporizer temperature and ion transfer tubing temperature are set at $200^{\circ} \mathrm{C}$. Sheath gas, auxiliary gas and sweep gas flows are set (arbitrary units) at 5, 2 and 0 , respectively. The mass spectrometer is a triple quadrupole that is calibrated with polytyrosine. Mass spectra are obtained under either full-scan mode or selected ion monitoring (SIM) mode.

In full-scan mode, RF lens voltages are the default from the optimization in the mass calibration. The SIM scan is achieved by isolating and monitoring a range of masses with maximum mass range of $50 \mathrm{Da}$. The RF lens voltages in SIM mode can be manually varied and are optimized to maximize the intensities of the ammonium adducts of the molecular ions.

Ion fragmentation in the MS/MS is accomplished by application of electrical potentials $(2-10 \mathrm{~V})$ and collision gas (Argon, $0.5 \mathrm{mTorr}$ ) in the collision-induced dissociation (CID) cell. Mass spectra from product scans are obtained by transmitting ions of a specific $m / z$ through the first quadrupole (precursor ions), fragmenting in the CID cell, and monitoring the resulting fragment ions (product ions) by the third quadrupole.

In the NL scan mode, the first and third quadrupoles are scanned at the same rate over mass ranges of the same width; i.e. the third quadrupole transmits ions at a fixed mass-tocharge ratio lower than the first quadrupole. In the NL scan, the CID voltage and argon pressure are set at $2-10 \mathrm{~V}$ and 0.5 mTorr, respectively. The limit of detection (LOD) of the analytical method is established by direct injection of the $\mathrm{ROOH}$ standard solution in $\mathrm{MeOH}$ with $2-10 \mathrm{mM}$ ammonium acetate into the APCI source with the tandem mass spectrometer being operated under NL scan mode. Three ROOH standards - namely 2-butanone peroxide, tert-butyl hydroperoxide and cumene hydroperoxide - are analyzed. Since a neutral loss of $51 \mathrm{Da}$ from the ammoniated molecular ion $\left(\left[\mathrm{M}+\mathrm{NH}_{4}\right]^{+}\right)$of the $\mathrm{ROOH}$ is characteristic for $\mathrm{ROOH}$ molecules, as will be seen in the next section, the calibration is performed by operating with a loss of $51 \mathrm{Da}$ in
NL scan. The ROOH concentrations are selected when the $\left[\mathrm{M}+\mathrm{NH}_{4}\right]^{+}$ions are well above the noise and clearly seen in the average mass spectra. The LOD is reported as 3 times the $S / N$ where noise is estimated at mass-to-charge ratios different from the mass-to-charge ratio for $\left[\mathrm{M}+\mathrm{NH}_{4}\right]^{+}$.

\section{Results and discussion}

\subsection{APCI mass spectra of ROOH standards}

Figure 1 presents examples of the direct infusion (+)-APCI mass spectra for (a) cumene hydroperoxide (cumene HP) and (b) 4,3-ISOPOOH, with and without addition of AA. The chemical structures and molecular weights (MWs) of the ROOH analyzed are given in Fig. S1 in the Supplement. Note that we do not attempt to interpret the mass spectra of $\mathrm{ROOH}$ and other standards obtained under full-scan and SIM modes due to the presence of stabilizers and other impurities in the standard samples that make the mass spectra complex. Instead, we focus on the protonated and ammoniated molecular ions of the ROOH molecules.

It can be seen from Fig. 1 that, although cumene HP demonstrates the proton adduct of the molecular ion at $m / z=153\left([\mathrm{M}+\mathrm{H}]^{+}\right.$(top panel of Fig. 1a), addition of AA results in the ammonium adduct at $m / z=170\left(\left[\mathrm{M}+\mathrm{NH}_{4}\right]^{+}\right)$ (bottom panel of Fig. 1a). For ISOPOOH, the molecular ion is not seen in the full-scan mass spectrum (top panel of Fig. 1b), and the dehydrated molecular ion at $m / z=101$ $\left(\left[\mathrm{M}+\mathrm{H}-\mathrm{H}_{2} \mathrm{O}\right]^{+}\right)$is clearly observed instead (top panel of Fig. 1b). This is consistent with previous studies claiming that hydroperoxy group (-OOH) is not a favorable protonation or deprotonation site with ESI or APCI (Reinnig et al., 2008; Rondeau et al., 2003; Nilsson et al., 2008). The addition of AA again leads to significant production of the ammonium adduct of the molecular ion at $m / z 136$ (bottom panel of Fig. 1b). Similar effects of AA on the APCI mass spectra are observed for other $\mathrm{ROOH}$ species.

In comparison, a number of other common molecules in atmospheric samples - e.g. ROOR, carbonyls, alcohols and carboxylic acids - were also analyzed. The chemical structures of the other oxygenated organics are given in Fig. S2. Similar to the ROOH samples, the ammonium adducts of the molecular ions $\left(\left[\mathrm{M}+\mathrm{NH}_{4}\right]^{+}\right)$are obtained for all the substances. The only difference is that in some cases, e.g. benzoyl peroxide, the ammonium adduct of the molecular ions can be clearly seen without addition of AA, via trace levels of ammonia present in the water or air.

\subsection{Product spectra of $\left[\mathrm{M}+\mathrm{NH}_{4}\right]^{+}$for $\mathrm{ROOH}$ and other organics}

Figure 2 gives the CID fragment patterns (i.e. product spectra) for ammonium adducts of the molecular ions ([M + $\left.\mathrm{NH}_{4}\right]^{+}$) of (a) cumene HP and (b) ISOPOOH. Two types of fragmentation, i.e. loss of 35 and $51 \mathrm{Da}$ from the respec- 

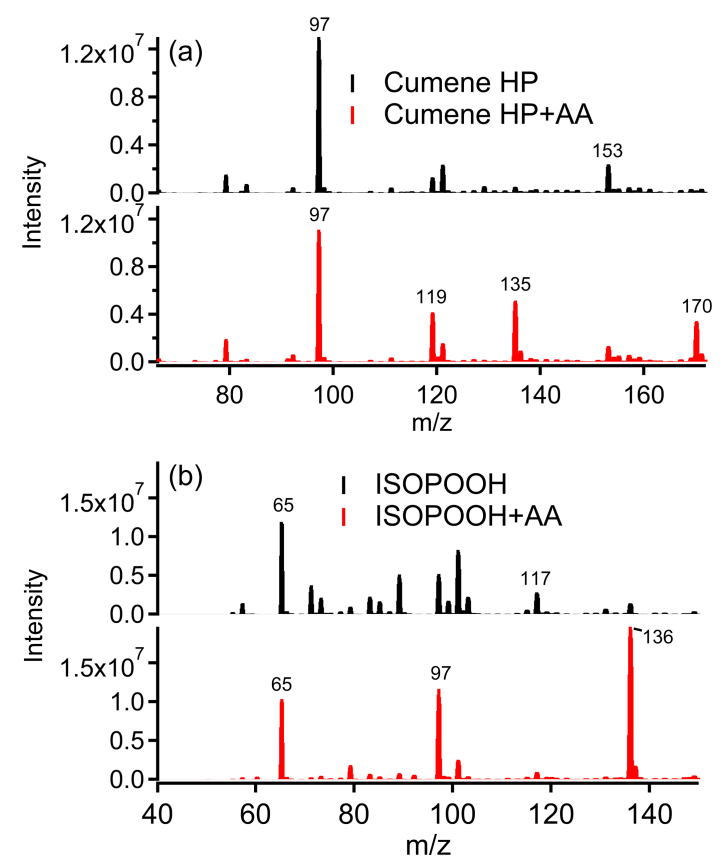

Figure 1. (+)-APCI mass spectra of ROOH with and without addition of ammonium acetate (AA) for (a) cumene HP and (b) ISOPOOH.

tive $\left[\mathrm{M}+\mathrm{NH}_{4}\right]^{+}$ions, are observed in both cumene $\mathrm{HP}$ and ISOPOOH. The loss of $35 \mathrm{Da}$, corresponding to $\left[-\mathrm{H}_{2} \mathrm{O}-\mathrm{NH}_{3}\right]$ (Fig. S3), is also observed in meso-erythritol and pinonic acid (Fig. S4). Neutral loss of $51 \mathrm{Da}$, corresponding to $\left[-\mathrm{H}_{2} \mathrm{O}_{2}\right.$ $\mathrm{NH}_{3}$ ] (Fig. S3), is only observed from fragmentation of the $\left[\mathrm{M}+\mathrm{NH}_{4}\right]^{+}$ions of $\mathrm{ROOH}$ (Figs. 2 and S4). It is known that the loss of the $\mathrm{H}_{2} \mathrm{O}$ molecule from protonated molecular ions $\left([\mathrm{M}+\mathrm{H}]^{+}\right)$is typical for epoxides, alcohols and carboxylic acids (Holcapek et al., 2010). But the loss of $35 \mathrm{Da}$ from $\left[\mathrm{M}+\mathrm{NH}_{4}\right]^{+}$is not characteristic for ROOH. Instead, the loss of $51 \mathrm{Da}$ from $\left[\mathrm{M}+\mathrm{NH}_{4}\right]^{+}$is only observed in $\mathrm{ROOH}$ standards, including peracetic acid (Fig. S5). Hence we propose that the neutral loss of $51 \mathrm{Da}$ from $\left[\mathrm{M}+\mathrm{NH}_{4}\right]^{+}$is characteristic for $\mathrm{ROOH}$ molecules. This is consistent with previous work that suggested that neutral loss of $\mathrm{H}_{2} \mathrm{O}_{2}$ from $[\mathrm{M}+\mathrm{H}]^{+}$is also characteristic for $\mathrm{ROOH}$ species (Reinnig et al., 2009).

\subsection{ROOH formation from the reactions of aldehydes and $\mathrm{H}_{2} \mathrm{O}_{2}$}

Using ${ }^{1} \mathrm{H}$ NMR spectroscopy, it has been shown that $\mathrm{ROOH}$ species form from the reactions of aldehydes with $\mathrm{H}_{2} \mathrm{O}_{2}$ (Zhao et al., 2013). As shown in Fig. 3, the reaction proceeds via reversible nucleophilic addition of $\mathrm{H}_{2} \mathrm{O}_{2}$ to the carbonyl group in aldehydes, leading to $\alpha$-hydroxyhydroperoxides (HHP). The addition of $\mathrm{H}_{2} \mathrm{O}_{2}$ to methylglyoxal (MGL; $\mathrm{MW}=72$ ) gives rise to MGL HHP (MW=106) (Fig. 3a), whose ammonium adduct is seen at $m / z 124$ in Fig. 4a. The
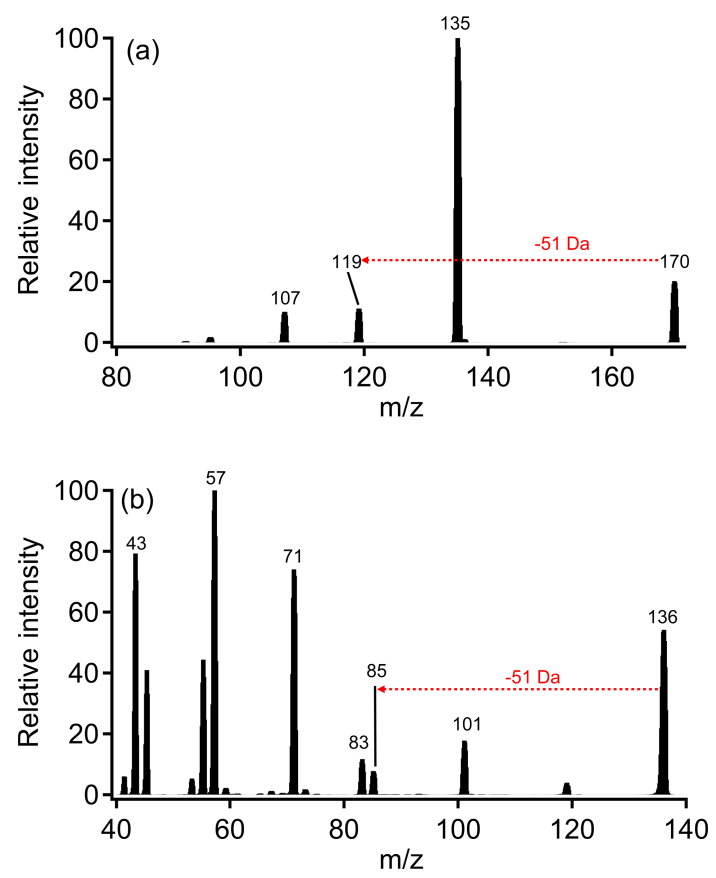

Figure 2. Product spectra of $\left[\mathrm{M}+\mathrm{NH}_{4}^{+}\right]^{+}$for (a) cumene $\mathrm{HP}$ and (b) ISOPOOH.

mass spectrum of the reaction mixture of glyoxal and $\mathrm{H}_{2} \mathrm{O}_{2}$ suggests that, rather than a direct addition to glyoxal, $\mathrm{H}_{2} \mathrm{O}_{2}$ is instead added to the glyoxal geminal diol formed by the hydrolysis of glyoxal (Fig. 3b), producing $\left[\mathrm{M}+\mathrm{NH}_{4}\right]^{+}$at $m / z 128$ (Fig. S6a). The $\left[\mathrm{M}+\mathrm{NH}_{4}\right]^{+} \mathrm{ROOH}$ peaks are also observed in the reactions of other aldehydes with $\mathrm{H}_{2} \mathrm{O}_{2}$ (data not shown).

The fragmentation spectra of the $\left[\mathrm{M}+\mathrm{NH}_{4}\right]^{+}$of the $\mathrm{ROOH}$ from methylglyoxal and glyoxal are given in Figs. 4b and S6b, respectively. It is clear that the neutral loss of $51 \mathrm{Da}$ is again observed in the fragments of the ROOH molecules. The $\mathrm{ROOH}$ products from all the other aldehyde reactions with $\mathrm{H}_{2} \mathrm{O}_{2}$ also show loss of $51 \mathrm{Da}$ in MS/MS mode. Overall, we conclude that the neutral loss of $51 \mathrm{Da}$ from $\left[\mathrm{M}+\mathrm{NH}_{4}\right]^{+}$fragmentation can be used to identify $\mathrm{ROOH}$ molecules.

\subsection{Identification of ROOH in SOA material}

Figure 5 presents mass spectra of the methanol extract of SOA generated from ozonolysis of $\alpha$-pinene under dry conditions (relative humidity $(\mathrm{RH})<5 \%$ ). There are three features of note. First, the well-characterized products from this reaction - such as nopinone aldehyde $(\mathrm{MW}=154)$, terpenylic acid $(\mathrm{MW}=172)$ and cis-pinic acid $(\mathrm{MW}=186)$ (Jenkin et al., 2000; Larsen et al., 2001; Claeys et al., 2009) - are present as protonated molecular ions $\left([\mathrm{M}+\mathrm{H}]^{+}\right)$in the full-scan mode (Fig. 5a). Second, the full-scan mass spectrum (Fig. 5a) shows the presence of monomer $(\mathrm{m} / \mathrm{z}=80$ $250)$, dimer $(m / z=250-450)$ and trimer $(m / z=450-600)$ 
(a)

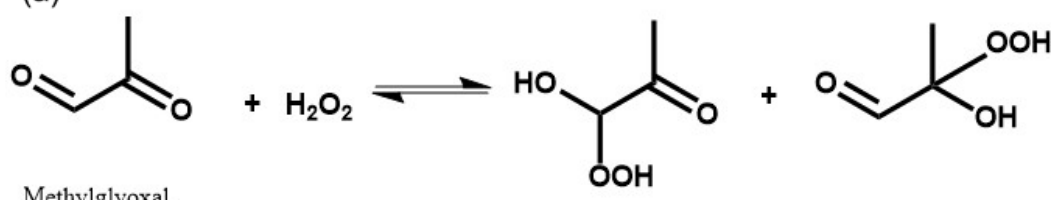

(MGL), MW=72

MGL HHP, MW=106

(b)

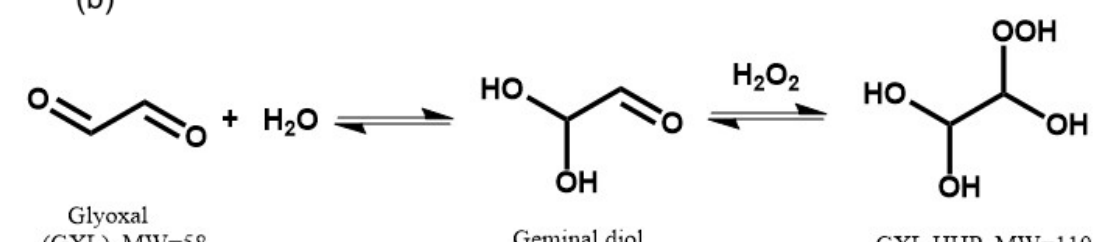

Figure 3. $\mathrm{ROOH}$ formation from reactions of $\mathrm{H}_{2} \mathrm{O}_{2}$ with (a) methylglyoxal and (b) glyoxal.
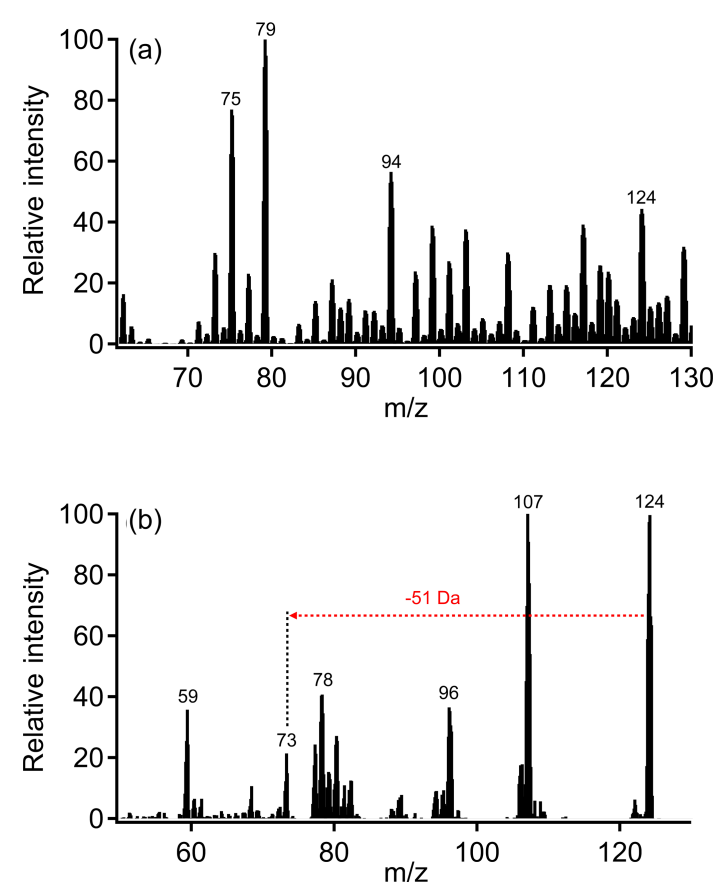

Figure 4. (a) Mass spectrum of reaction of methylglyoxal with $\mathrm{H}_{2} \mathrm{O}_{2}$ in the presence of AA; (b) product mass spectrum of $m / z 124$ from panel (a).

species, as has been reported in previous work (Venkatachari and Hopke, 2008). Third, and perhaps most importantly, the 51 Da neutral loss scan (Fig. 5b) indicates that all the ROOH species have masses $<300 \mathrm{Da}$ (Fig. 5b).

To confirm the observation of $\mathrm{ROOH}$ obtained with the neutral loss scan, CID fragmentation spectra of a few intense peaks at $m / z$ 190, 202, 206, 218 and 220 in Fig. 5b are analyzed. All the fragments of these products show loss of $51 \mathrm{Da}$. An example of the fragment pattern for $m / z 206$ is given in Fig. S7.

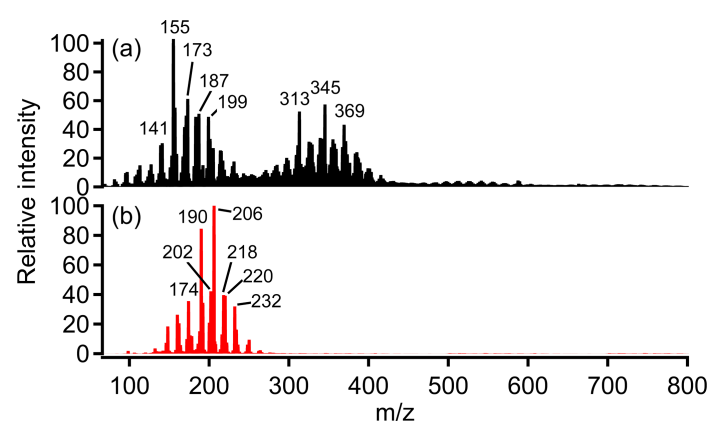

Figure 5. Mass spectra of SOA from ozone reaction with $\alpha$-pinene under dry conditions $(\mathrm{RH}<5 \%)$ obtained with (a) full scan and (b) neutral loss scan of $51 \mathrm{Da}$.

The $\mathrm{ROOH}$ products in SOA are tentatively identified and listed in Table 1. It should be noted that the chemical structures of these products are only obtained from their molecular ions and, therefore, remain speculative.

Several mechanisms for oligomer product formation in SOA arising from VOC oxidation have been proposed: (i) self- and cross-reactions of the peroxy radicals $\left(\mathrm{RO}_{2}\right)$ (Zhang et al., 2015); (ii) reaction of ozonolysis products in the condensed-phase, such as aldol condensation, esterification, hemiacetal and peroxyhemiacetal formation (Ziemann, 2003; Tolocka et al., 2004; Kristensen et al., 2014; Docherty et al., 2005; Muller et al., 2009; Yasmeen et al., 2010; Hall and Johnston, 2012; Witkowski and Gierczak, 2014; DePalma et al., 2013; Lim and Turpin, 2015); (iii) dimer cluster formation from carboxylic acids (Hoffmann et al., 1998; Tobias and Ziemann, 2000; Claeys et al., 2009; Camredon et al., 2010; DePalma et al., 2013); (iv) reactions of Criegee intermediates (CIs) with VOCs oxidation products (Bonn et al., 2002; Lee and Kamens, 2005; Tolocka et al., 2006; Heaton et al., 2007; Witkowski and Gierczak, 2012; Kristensen et al., 2016; Wang et al., 2016); and (v) reactions of $\mathrm{RO}_{2}$ radicals 
Table 1. Possible identities of the ROOH in $\alpha$-pinene SOA.

Molecular
$\left(\left[\mathrm{M}+\mathrm{NH}_{4}{ }^{+}\right]^{+}\right)$
weight (MW)

with Cis (Sadezky et al., 2008; Zhao et al., 2015). Among them, the reactions of CIs with protic substances (water, alcohols, acids and hydroperoxides) can form ROOH. However, the nature of the $\mathrm{ROOH}$ products observed in SOA material suggests that these reactions do not take place to a significant extent given that $\mathrm{ROOH}$ do not contribute significantly to the dimer and trimer SOA signals (Fig. 5b). The similar mass patterns for the SOA and ROOH obtained under dry $(\mathrm{RH}<5 \%)$ and humid $(\mathrm{RH}=50 \%)$ conditions support this conclusion (Fig. S9). Of course, we can not rule out that the oligomeric ROOH may not be sensitive with the analytical method used. Additionally, while the $\mathrm{ROOH}$ formation mechanisms are proposed via gas-phase ozonolysis of $\alpha$-pinene (Fig. S8), the ROOH observed in the SOA could also potentially be arising from the decomposition of peroxyhemiacetals during methanol extraction.

In the neutral loss scan mode, the LOD were measured to be $0.2,0.3$ and $20 \mathrm{mM}$ for 2-butanone peroxide, cumene hydroperoxide and tert-butyl hydroperoxide, respectively. The LODs obtained by this method are a rough estimation and will vary dependent on a number of parameters: ionization voltage, sample injection flow, gas flow, CID gas pressure, $\mathrm{CID}$ voltages etc. More importantly, if a specific $\mathrm{ROOH}$ is to be analyzed, then multiple reaction monitoring mode would be applied and the LOD of the ROOH would be substantially reduced.

\section{Conclusions}

Organic hydroperoxides are molecules of crucial importance to atmospheric chemistry, arising under VOC oxidation schemes that proceed under low- $\mathrm{NO}_{x}$ conditions. Indeed, as $\mathrm{NO}_{x}$ levels continue to drop throughout many parts of the atmosphere through emission control measures, it is expected that these species will become even more prevalent. Furthermore, many of these ROOH molecules are known to constitute an important component of secondary organic aerosol material. Once in atmospheric particles, ROOH can participate in condensed-phase reactions, including nucleophilic processes and photolysis, and they are likely harmful when deposited into lung fluid.

A major complication in the study of ROOH chemistry has been the lack of detection techniques that are able to identify different ROOH species. In this work we present an offline method for the identification of aqueous-phase $\mathrm{ROOH}$ molecules which involves first ionization by adduct formation with ammonium ions and then collision-induced dissociation by a unique fragmentation pathway involving the simultaneous loss of both $\mathrm{NH}_{3}$ and $\mathrm{H}_{2} \mathrm{O}_{2}$. Although only a fraction of the total ion fragmentation pathway involves $51 \mathrm{Da}$ neutral loss, the specificity of the tandem mass spectrometry approach will yield low detection limits.

We illustrate the utility of this analytical method by demonstrating that a set of $\mathrm{ROOH}$ molecules is present in $\alpha$-pinene ozonolysis SOA, all arising from known oxidation mechanisms. Perhaps most interestingly, ROOH species were not observed to be present in the oligomeric fraction of $\alpha$-pinene ozonolysis SOA, indicating that reactions such as Criegee radicals reacting with protic substances are not a source of such dimeric and trimeric molecules (Lim and Turpin, 2015). In this manner, we believe that this new analytical approach could be used widely to decipher the prevalence of ROOH molecules in different forms of SOA. Given the specificity of the method, it could also be used to monitor the kinetics of condensed-phase reactions of individual ROOH molecules.

Although this work focused on the use of this new analytical method to analyze for atmospheric ROOH molecules, 
it could equally well be applied to the detection of $\mathrm{ROOH}$ molecules in other systems, especially biological ones.

Data availability. Data are available upon request from Jonathan P. D. Abbatt (jabbatt@ chem.utoronto.ca).

\section{The Supplement related to this article is available online at https://doi.org/10.5194/amt-11-3081-2018-supplement.}

Competing interests. The authors declare that they have no conflict of interest.

Acknowledgements. This work was supported by the Alfred P. Sloan Foundation and NSERC. Frank N. Keutsch and Jean C. Rivera-Rios would also like to acknowledge the support of the National Science Foundation (AGS 1628491, 1628530, 1247421 and 1321987).

Edited by: Pierre Herckes

Reviewed by: three anonymous referees

\section{References}

Agon, V. V., Bubb, W. A., Wright, A., Hawkins, C. L., and Davies, M. J.: Sensitizer-mediated photooxidation of histidine residues: evidence for the formation of reactive side-chain peroxides, Free Radical Bio. Med., 46, 698-710, 2006.

Aljawhary, D., Lee, A. K. Y., and Abbatt, J. P. D.: High-resolution chemical ionization mass spectrometry (ToF-CIMS): application to study SOA composition and processing, Atmos. Meas. Tech., 6, 3211-3224, https://doi.org/10.5194/amt-6-3211-2013, 2013.

Atkinson, R. and Arey, J.: Atmospheric degradation of volatile organic compounds, Chem. Rev., 103, 4605-4638, 2003.

Bach, R. D., Ayala, P. Y., and Schlegel, H. B.: A reassessment of the bond dissociation energies of peroxides. An ab Initio study, J. Am. Chem. Soc., 118, 12857-12765, 1996.

Banerjee, D. K. and Budke, C. C.: Spectrophotometric determination of traces of peroxides in organic solvents, Anal. Chem., 36, 792-796, 1964.

Bonn, B., Schuster, G., and Moortgat, G. K.: Influence of water vapor on the process of new particle formation during monoterpene ozonolysis, J. Phys. Chem. A, 106, 2869-2881, 2002.

Bonn, B., von Kuhlmann, R., and Lawrence, M. G.: High contribution of biogenic hydroperoxides to secondary organic aerosol formation, Geophys. Res. Lett., 31, L10108, https://doi.org/10.1029/2003GL019172, 2004.

Camredon, M., Hamilton, J. F., Alam, M. S., Wyche, K. P., Carr, T., White, I. R., Monks, P. S., Rickard, A. R., and Bloss, W. J.: Distribution of gaseous and particulate organic composition during dark $\alpha$-pinene ozonolysis, Atmos. Chem. Phys., 10, 2893-2917, https://doi.org/10.5194/acp-10-2893-2010, 2010.
Claeys, M., Iinuma, Y., Szmigielski, R., Surratt, J. D., Blockhuys, F., Van Alsenoy, C., Böge, O., Sierau, B., GomezGonzalez, Y., Vermeylen, R., Van Der Veken, P., Shahgholi, M., Chan, A. W. H., Herrmann, H., Seinfeld, J. H., and Maenhaut, W.: Terpenylic acid and related compounds from the oxidation of $\alpha$-pinene: Implications for new particle formation and growth above forests, Environ. Sci. Technol., 43, 6976-6982, 2009.

DePalma, J. W., Horan, A. J., Hall, W. A., and Johnston, M. V.: Thermodynamics of oligomer formation: implications for secondary organic aerosol formation and reactivity, Phys. Chem. Chem. Phys., 15, 6935-6944, 2013.

Docherty, K. S., Wu, W., Lim, Y. B., and Ziemann, P. J.: Contributions of organic peroxides to secondary aerosol formed from reactions of monoterpenes with $\mathrm{O}_{3}$, Environ. Sci. Technol., 39, 4049-4059, 2005.

Francois, S., Sowka, I., Monod, A., Temime-Roussel, B., Laugier, J. M., and Wortham, H.: Development of an online analyzer of atmospheric $\mathrm{H}_{2} \mathrm{O}_{2}$ and several organic hydroperoxides for field campaigns, Atmos. Res., 74, 525-545, 2005.

Gebicki, S. and Gebicki, J. M.: Formation of peroxides in amino acids and proteins exposed to oxygen free radicals, Biochem. J., 289, 743-749, 1993.

Hall, W. A. and Johnston, M. V.: Oligomer formation pathways in secondary organic aerosol from MS and MS/MS measurements with high mass accuracy and resolving power, J. Am. Soc. Mass Spectr., 23, 1097-1108, 2012.

Hasson, A. S., Ho, A. W., Kuwata, K. T., and Paulson, S. E.: Production of stabilized Criegee intermediates and peroxides in the gas phase ozonolysis of alkenes. 2. Asymmetric and biogenic alkenes, J. Geophys. Res., 106, 34143-34153, 2001.

Heaton, K. J., Dreyfus, M. A., Wang, S., and Johnston, M. V.: Oligomer in the early stage of biogenic secondary organic aerosol formation and growth, Environ. Sci. Technol., 41, 61296136, 2007.

Hoffmann, T., Bandur, R., Marggraf, U., and Linscheid, M.: Molecular composition of organic aerosols formed in the $\alpha$-pinene $/ \mathrm{O}_{3}$ reaction: implication for new particle formation processes, J. Geophys. Res., 103, 25569-25578, 1998.

Holcapek, M., Jirasko, R., and Lisa, M.: Basic rules for the interpretation of atmospheric pressure ionization mass spectra of small molecules, J. Chromatogr. A, 1217, 3908-3921, 2010.

Hong, S. B., Kim, G. S., Kang, C. H., and Lee, J. H.: Measurement of ambient hydroperoxides using an automated HPLC system and various factors which affect variations of their concentrations in Korea, Environ. Monit. Assess., 147, 23-34, 2008.

Hui, S.-P., Sakurai, T., Ohkawa, F., Furumaki, H., Jin, S., Fuda, H., Takeda, S., Kurosawa, T., and Chiba, H.: Detection and characterization of cholesteryl ester hydroperoxides in oxidized LDL and oxidized HDL by use of an Orbitrap mass spectrometer, Anal. Bioanal. Chem., 404, 101-112, 2012a.

Hui, S.-P., Taguchi, Y., Takeda, S., Ohkawa, F., Sakurai, T., Yamaki, S., Jin, S., and Fuda, H.: Quantitative determination of phosphatidylcholine hydroperoxides during copper oxidation of LDL and HDL by liquid chromatography/mass spectrometry, Anal. Bioanal. Chem., 403, 1831-1840, 2012b.

Jackson, A. V. and Hewitt, C. N.: Atmospheric hydrogen peroxide and organic hydroperoxides: A review, Environ. Sci. Technol., 29, 175-228, 1999. 
Jenkin, M. E.: Modelling the formation and composition of secondary organic aerosol from $\alpha$ - and $\beta$-pinene ozonolysis using MCM v3, Atmos. Chem. Phys., 4, 1741-1757, https://doi.org/10.5194/acp-4-1741-2004, 2004.

Jenkin, M. E., Shallcross, D. E., and Harvey, J. N.: Development and application of a possible mechanism for the generation of cis-pinic acid from the ozonolysis of $\alpha$ - and $\beta$-pinene, Atmos. Environ., 34, 2837-2850, 2000.

Krapf, M., Haddad, I. E., Bruns, E. A., Molteni, U., Daellenbach, K. R., Prevot, A. S. H., Baltensperger, U., and Dommen, J.: Labile peroxides in secondary organic aerosol, Chemistry, 1, 603-616, 2016.

Kristensen, K., Cui, T., Zhang, H., Gold, A., Glasius, M., and Surratt, J. D.: Dimers in $\alpha$-pinene secondary organic aerosol: effect of hydroxyl radical, ozone, relative humidity and aerosol acidity, Atmos. Chem. Phys., 14, 4201-4218, https://doi.org/10.5194/acp-14-4201-2014, 2014.

Kristensen, K., Watne, Å. K., Hammes, J., Lutz, A., Petäjä, T., Hallquist, M., Bilde, M., and Glasius, M.: High-molecular weight dimer esters are major products in aerosols from $\alpha$-pinene ozonolysis and the boreal forest, Environ. Sci. Tech. Let., 3, 280285, 2016.

Larsen, B. R., Di Bella, D., Glasius, M., Winterhalter, R., Jensen, N. S., and Hjorth, J.: Gas-phase $\mathrm{OH}$ oxidation of monoterpenes: gaseous and particulate products, J. Atmos. Chem., 38, 231-276, 2001.

Lee, M., Heikes, B. G., and O'Sullivan, D. W.: Hydrogen peroxide and organic hydroperoxide in the troposphere: A review, Atmos. Environ., 34, 3475-3494, 2000.

Lee, S. and Kamens, R. M.: Particle nucleation from the reaction of $\alpha$-pinene and $\mathrm{O}_{3}$, Atmos. Environ., 39, 6822-6832, 2005.

Lim, Y. B. and Turpin, B. J.: Laboratory evidence of organic peroxide and peroxyhemiacetal formation in the aqueous phase and implications for aqueous OH, Atmos. Chem. Phys., 15, 1286712877, https://doi.org/10.5194/acp-15-12867-2015, 2015.

Liou, G.-Y. and Storz, P.: Reactive oxygen species in cancer, Free Radical Res., 44, 479-496, https://doi.org/10.3109/10715761003667554, 2010.

Moll, C., Biermann, U., and Grosch, W.: Occurrence and formation of bitter-tasting trihydroxy fatty acids in soybeans, J. Agr. Food Chem., 27, 239-243, 1979.

Morgan, P. M., Pattison, D. I., Hawkins, C. L., and Davies, M. J.: Separation, detection, and quantification of hydroperoxides formed at side-chain and backbone sites on amino acids, peptides, and proteins, Free Radical Bio. Med., 45, 1279-1289, 2008.

Muller, L., Reinnig, M. C., Hayen, H., and Hoffmann, T.: Characterization of oligomeric compounds in secondary organic aerosol using liquid chromatography coupled to electrospray ionization Fourier transform ion cyclotron resonance mass spectrometry, Rapid Commun. Mass Sp., 23, 971-979, 2009.

Nakamura, T. and Maeda, H.: A simple assay for lipid hydroperoxides based on triphenylphosphine oxidation and highperformance liquid chromatography, Lipids, 26, 765-768, 1991.

Nilsson, J., Carlberg, J., Abrahamsson, P., Hulthe, G., Persson, B. A., and Karlberg, A. T.: Evaluation of ionization techniques for mass spectrometric detection of contact allergenic hydroperoxides formed by autoxidation of fragrance terpenes, Rapid Commun. Mass Sp., 22, 3593-3598, 2008.
Odian, G.: Principles of Polymerization, 4th ed., WileyInterscience, New York, USA, 2004.

Reile, I., Paju, A., Müürisepp, A.-M., Pehk, T., and Lopp, M.: Oxidation of cyclopentane-1,2-dione: a study with ${ }^{18} \mathrm{O}$ labeled reagents, Tetrahedron, 67, 5942-5948, 2011.

Reinnig, M. C., Mueller, L., Warnke, J., and Hoffmann, T.: Characterization of selected organic compound classes in secondary organic aerosol from biogenic VOCs by HPLC/MSn, Anal. Bioanal. Chem., 391, 171-182, 2008.

Reinnig, M. C., Warnke, J., and Hoffmann, T.: Identification of organic hydroperoxides and hydroperoxy acids in secondary organic aerosol formed during the ozonolysis of different monoterpenes and sesquiterpenes by on-line analysis using atmospheric pressure chemical ionization ion trap mass spectrometry, Rapid Commun. Mass Sp., 23, 1735-1741, 2009.

Riva, M., Budisulistiorini, S. H., Zhang, Z., Gold, A., Thornton, J. A., Turpin, B. J., and Surratt, J. D.: Multiphase reactivity of gaseous hydroperoxide oligomers produced from isoprene ozonolysis in the presence of acidified aerosols, Atmos. Environ., 152, 314-322, 2017.

Rivera-Rios, J. C., Nguyen, T. B., Crounse, J. D., Jud, W., St. Clair, J. M., Mikoviny, T., Gilman, J. B., Lerner, B. M., Kaiser, J. B., de Gouw, J., Wisthaler, A., Hansel, A., Wennberg, P. O., Seinfeld, J. H., and Keutsch, F. N.: Conversion of hydroperoxides to carbonyls in field and laboratory instrumentation: Observational bias in diagnosing pristine versus anthropogenically controlled atmospheric chemistry, Geophys. Res. Lett., 41, 8645-8651, 2014.

Rondeau, D., Vogel, R., and Tabet, J. C.: Unusual atmospheric pressure chemical ionization conditions for detection of organic peroxides, J. Mass Spectrom., 38, 931-940, 2003.

Sadezky, A., Winterhalter, R., Kanawati, B., Römpp, A., Spengler, B., Mellouki, A., Le Bras, G., Chaimbault, P., and Moortgat, G. K.: Oligomer formation during gas-phase ozonolysis of small alkenes and enol ethers: new evidence for the central role of the Criegee Intermediate as oligomer chain unit, Atmos. Chem. Phys., 8, 2667-2699, https://doi.org/10.5194/acp-8-2667-2008, 2008.

Sakamoto, Y., Yajima, R., Inomata, S., and Hirokawa, J.: Water vapour effects on secondary organic aerosol formation in isoprene ozonolysis, Phys. Chem. Chem. Phys., 19, 3165-3175, 2017.

Tobias, H. J. and Ziemann, P. J.: Thermal desorption mass spectrometric analysis of organic aerosol formed from reactions of 1-tetradecene and $\mathrm{O}_{3}$ in the presence of alcohols and carboxylic acids, Environ. Sci. Technol., 34, 2105-2115, 2000.

Tolocka, M. P., Jang, M., Ginter, J. M., Cox, F. J., Kamens, R. M., and Johnston, M. V.: Formation of oligomers in secondary organic aerosol, Environ. Sci. Technol., 38, 1428-1434, 2004.

Tolocka, M. P., Heaton, K. J., Dreyfus, M. A., Wang, S. Y., Zordan, C. A., Saul, T. D., and Johnston, M. V.: Chemistry of particle inception and growth during $\alpha$-pinene ozonolysis, Environ. Sci. Technol., 40, 1843-1848, 2006.

Valverde-Canossa, J., Wieprecht, W., Acker, K., and Moortgat, G. K.: $\mathrm{H}_{2} \mathrm{O}_{2}$ and organic peroxide measurements in an orographic cloud: The FEBUKO experiment, Atmos. Environ., 39, 4279-4290, 2005. 
Venkatachari, P. and Hopke, P. K.: Characterization of products formed in the reaction of ozone with $\alpha$-pinene: Case for organic peroxides, J. Environ. Monitor., 10, 966-974, 2008.

Walker, S. J., Evans, M. J., Jackson, A. V., Steinbacher, M., Zellweger, C., and McQuaid, J. B.: Processes controlling the concentration of hydroperoxides at Jungfraujoch Observatory, Switzerland, Atmos. Chem. Phys., 6, 5525-5536, https://doi.org/10.5194/acp-6-5525-2006, 2006.

Wang, M., Yao, L., Zheng, J., Wang, X., Chen, J., Yang, X., Worsnop, D. R., Donahue, N. M., and Wang, L.: Reactions of atmospheric particulate stabilized Criegee intermediates lead to high-molecular-weight aerosol components, Environ. Sci. Technol., 50, 5702-5710, 2016.

Wasylaschuk, W. R., Harmon, P. A., Wagner, G., Harman, A. B., Templeton, A. C., Xu, H., and Reed, R. A.: Evaluation of hydroperoxides in common pharmaceutical excipients, J. Pharm. Sci., 96, 106-116, 2007.

Witkowski, B. and Gierczak, T.: Early stage composition of SOA produced by $\alpha$-pinene/ozone reaction: $\alpha$-Acyloxyhydroperoxy aldehydes and acidic dimers, Atmos. Environ., 95, 59-70, 2014.

Wright, A., Bubb, W. A., Haekins, C. L., and Davis, M. J.: Singlet oxygen-mediated protein oxidation: Evidence for the formation of reactive side chain peroxides on tyrosine residues, Photochem. Photobiol., 76, 35-46, 2002.

Yasmeen, F., Vermeylen, R., Szmigielski, R., Iinuma, Y., Böge, O., Herrmann, H., Maenhaut, W., and Claeys, M.: Terpenylic acid and related compounds: precursors for dimers in secondary organic aerosol from the ozonolysis of $\alpha$ - and $\beta$-pinene, Atmos. Chem. Phys., 10, 9383-9392, https://doi.org/10.5194/acp10-9383-2010, 2010.
Zhang, X., McVay, R. C., Huang, D. D., Dalleska, N. K., Aumont, B., Flagan, R. C., and Seinfeld, J. H.: Formation and evolution of molecular products in $\alpha$-pinene secondary organic aerosol, P. Natl. Acad. Sci. USA, 112, 14168-14173, 2015.

Zhang, X., Lambe, A. T., Upshur, M. A., Brooks, W. A., Be, A. G., Thomson, R. J., and Geiger, F. M.: Hihgly oxygenated multifunctional compounds in $\alpha$-pinene secondary organic aerosol, Environ. Sci. Technol., 51, 5932-5940, 2017.

Zhao, R., Lee, A. K. Y., Soong, R., Simpson, A. J., and Abbatt, J. P. D.: Formation of aqueous-phase $\alpha$-hydroxyhydroperoxides $(\alpha$ HHP): potential atmospheric impacts, Atmos. Chem. Phys., 13 5857-5872, https://doi.org/10.5194/acp-13-5857-2013, 2013.

Zhao, Y., Wingen, L. M., Perraud, V., Greaves, J., and FinlaysonPitts, B. J.: Role of the reaction of stabilized Criegee intermediates with peroxy radicals in particle formation and growth in air, Phys. Chem. Chem. Phys., 17, 12500-12514, 2015.

Ziemann, P. J.: Formation of alkoxyhydroperoxy aldehydes and cyclic peroxyhemiacetals from reactions of cyclic alkenes with $\mathrm{O}_{3}$ in the presence of alcohols, J. Phys. Chem. A, 107, 20482060, 2003. 